\title{
PEMBERDAYAAN FUNGSI BELAHAN KANAN OTAK UNTUK MENINGKATKAN KEMAMPUAN BERBAHASA KREATIF DAN HOLISTIS PADA ANAK (Sebuah Tinjauan Neurolinguistik)
}

\author{
Puji Lestari
}

\begin{abstract}
Abstrak
Fenomena mengenai ketimpangan kurikulum pendidikan di Indonesia saat ini cukup memprihatinkan. Penekanan dalam pengajaran diberikan dan diarahkan pada pemantapan fungsi otak kiri saja. Hal ini tentu saja mempengaruhi kemampuan dan pola pikir generasi pelajar kita yang tercermin pada hasil pendidikan yang mencetak manusia berpemikiran otak kiri yang lemah dalam daya kreasi dan inovasi serta aplikasi. Dan yang paling penting adalah bahwa mereka lemah dalam kemampuan berbahasa dan berkomunikasi secara kreatif, efektif dan holistik. Para perancang kurikulum pendidikan, teruutama pendidikan pra sekolah telah berusaha mengakomodir kebutuhan akan pemberdayaan fungsi belahan kanan otak. Namun sayangnya, pihak praktisi dan bahkan para orang tua justru cenderung mengutamakan penguasaan pengetahuan kognitif oleh siswa didik atau anaknya.

Pembahasan dalam makalah ini dibatasi pada permasalahan mengenai usahausaha pemberdayaan fungsi belahan otak kanan untuk meningkatkan kemampuan berbahasa pada anak. Dengan demikian, pembahasan ini ditujukan untuk memberikan penjelasan tentang kurikulum pendidikan pra sekolah yang berimbang dan strategi pembelajaran bahasa yang efektif dan efisien sehingga dapat mengembangkan belahan kanan otak untuk meningkatkan kemampuan bahasa anak yang kreatif dan utuh. Selanjutnya, pembahasan ini diharapkan dapat memberikan manfaat, baik secara praktis maupun teoritis, yaitu antara lain sebagai masukan bagi kalangan pendidikan atau guru dan orang tua serta masyarakat dalam hal pendidikan bahasa anak, di samping dapat meranngsang timbulnya pembahasan lebih lanjut mengenai permasalahan ini.

Dengan mengadakan kajian neurolinguistik, khususnya yang menyangkut kaitan fungsi otak dan bahasa, faktor-faktor pemerolehan bahasa serta tahap perkembangan bahasa pada anak, dapat ditentukan program pembelajaran yang tepat untuk diterapkan dalam pembelajaran bahasa pada anak. Namun demikian, kurikulum pendidikan pra sekolah yang sudah ada perlu dijadikan acuan untuk dikaji lebih lanjut substansi-substansinya sebagai bahan pertimbangan untuk pengembangan program pembelajaran yang lebih sempurna. Selain itu, dengan memperhatikan dan menjadikan "cara anak" sebagai acuan, maka dapat disusun strategi pembelajaran yang efisien.

Dari pembahasan yang berdasarkan teori neurolinguistik tersebut, dapat disimpulkan bahwa: (i) kurikulum pembelajaran bahasa yang diterapkan di Indonesia
\end{abstract}


saat ini masih berat sebelah dalam hal penguasaan kemampuan bahasa yang utuh; (ii) strategi pemerolehan bahasa yang mengacu pada siasat belajar "anak" perlu dipertimbangkan dalam pembelajaran bahasa yang efektif pada anak. Dari kesimpulan tersebut, kiranya kita perlu segera melakukan tindak lanjut demi meningkatkan kualitas generasi muda Indonesia, dengan menyusun suatu kurikulum yang handal dan berimbang sehinggga dapat meningkatkan fungsi kedua belahan otak secara optimal. Di samping itu, strategi pembelajaran yang efisien dan dapat mengembangkan daya kreasi dan inovasi anak sudah selayaknya diterapkan dalam pendidikan anak-anak.

\section{BAB I \\ PENDAHULUAN}

\subsection{Latar Belakang}

Selama ini banyak persepsi yang salah mengenai konsep umum proses pemerolehan dan perkembangan bahasa yang berkembang di masyarakat, terutama di kalangan para orang tua. Sebagian orang tua bersikap optimis dengan beranggapan bahwa anak secara alamiah telah memiliki kemampuan untuk belajar berbahasa. Apabila pada perkembangannya anak mengalami keterlambatan, si orang tua hanya mengambil sikap menunggu dengan harapan anak dapat menyusul (catch up) dan kembali meneruskan perkembangannya secara normal. Karena pandangan dan sikap yang salah ini, banyak kasus gangguan wicara pada anak yang tidak terdeteksi lebih awal, sehingga usaha pengobatannya pun sudah terlambat dan sulit dilakukan.

Sementara itu, sebagian orang tua yang lain cenderung bersikap pesimis terhadap proses pemerolehan bahasa anaknya. Mereka berpendapat bahwa pembelajaran anak harus dibantu dan didukung dengan suatu program kurikulum yang baik. Namun demikian, pada prakteknya mereka kebanyakan mengambil jalan yang salah dalam pembinaan dan pengasuhan perilaku berbahasa anaknya, meskipun 
kesalahan ini tidak sepenuhnya berasal dari orang tua. Banyak ahli pendidikan yang menyatakan bahwa kurikulum pembelajaran yang diterapkan di Indonesia saat ini masih kurang memadai. Simanjuntak (1991: 9) secara garis besar mengemukakan bahwa pendidikan di Indonesia masih berat sebelah, yaitu memberi penekanan yang terlalu besar pada penguasaan ideasi bahasa daripada ideasi keterampilan pragmatik. Sering terjadi metode pengajaran bahsa di sekolah kurang memenfaatkan semua bagian pusat bahasa dan tidak mengikutsertakan hemisfer kanan otak. Dengan kata lain sekolah kita pada dasarnya hanya mencetak manusia berpemikiran otak kiri, yaitu orang yang kurang kreatif dan tidak inovatif, artinya sekalipun ia mungkin tahu suatu ilmu pengetahuan secara sistematis ia tidak tahu menrapkannya. Di lain pihak, kita juga tidak perlu menyangkal adanya kekurangan-kekurangan pada kebanyakan siswa di Indonesia yang ditemukan di dalam forum-forum komunikasi ilmiah. Kita sering mendapati siswa, termasuk mahasiswa yang kurang mampu menyampaikan ide-ide secara runtut dan sistematis, mengotrol emosi serta sering menyerobot pembicaraan orang lain, misalnya dalam ajang dialog atau debat. Secara tidak langsung fenomena ini merupakan indikator kurangnya kontrol pada belahan kanan otak selama proses interaksi. Jika ditelaah lebih lanjut, pertimbangan dari segi neurologis saat ini sudah sangat mendesak dan diperlukan dalam penyusunan program pendidikan agar diperoleh kualitas anak yang utuh.

\subsection{Identifikasi dan Pembatasan Masalah}

Penanaman perilaku bahasa yang baik sekaligus kreatif perlu dilakukan sedini 
mungkin. Hal ini dimaksudkan agar diperoleh landasan yang kokoh dalam perkembangan kemampuan berkomunikasi efektif dalam kehidupan sosial pada masamasa selanjutnya. Kata-kata dini di sini tentu saja dapat di interpretasikan seluasluasnya, dalam artian sebagai suatu titik awal waktu yang dimulai sejak masa pre natal atau setelah kelahiran hingga anak memasuki dunia pendidikan formal atau mungkin lebih luas lagi.

Di antara rentang waktu ini terdapat suatu periode yang menandai saat kritis anak terhadap rangsangan-rangsangan bahasa. Selain itu juga terdapat proses lateralisasi fungsi belahan otak yang sangat signifikan dan menetukan kemampuan berbahasa yang terjadi antara usia dua sampai empat atau lima tahun. Stimulusstimulus yang dapat mengembangkan fungsi kedua belahan otak ini harus diberikan secara proporsional dan efektif dengan memperhatikan pertumbuhan dan kematangan psikologis anak. Hal ini dapat terwujud dalam suatu program pembelajaran bahasa yang kooperatif terhadap tujuan tersebut.

Sementara ini, program pembelajaran bahasa untuk anak-anak, terutama usia pra sekolah, sebagaimana yang terdapat dalam kurikulum pendidikan Taman Kanakkanak secara garis besar telah berusaha mengakomodir fungsi dan tujuan pembelajaran bahasa tersebut. Namun, justru yang sangat memprihatinkan adalah tenaga pengajar di TK, dengan kemampuan interpretasi kurikulum yang berbeda-beda dan didukung apersepsi yang kurang tepat telah menerjemahkan isi kurikulum tersebut ke dalam suatu bentuk kegiatan belajar yang justru menghambat optimasi fungsi kedua belahan otak. Sebagai contoh, kegiatan menulis, membaca dan berhitung, yang merupakan 
kerja fungsi otak kiri, sudah diberikan meskipun dari segi kematangan psikologis dan pemantapan fungsi otak belum mencapai tahap kegiatan motorik tersebut, dan sebaliknya menghambat perkembangan otak kanan yang membawahi kematangan psikomotorik itu sendiri. Sayangnya, dengan alasan "prestige" dan kepuasan tertentu, orang tua malah akan merasa bangga jika anak-anaknya memperoleh pelajaran semacam itu di TK. Kecenderungan ini ditunjukkan dengan banyaknya orang tua yang memilih memasukkan anak-anaknya ke TK yang mengajari siswanya menulis, membaca dan berhitung dan bukannya yang bermain saja.

Hal ini ternyata cukup menarik untuk dibahas lebih jauh untuk kemudian ditindak lanjuti dengan antisipasi yang nyata dari perbaikan mutu pendidikan pra sekolah dan masa depan generasi muda kita. Oleh karena itu, pembahasan dalam makalah ini, akan dibatasi pada masalah usaha-usaha pemberdayaan fungsi belahan kanan otak untuk meningkatakan kemampuan berbahasa pada anak, terutama diarahkan untuk usia pra sekolah.

\subsection{Rumusan Masalah}

Berdasarkan identifikasi dan pembatasan masalah yang ada, maka masalah yang muncul adalah:

a. Bagaimanakah kurikulum yang seharusnya digunakan untuk memberdayakan kedua belahan otak untuk memperoleh kemampuan bahasa yang utuh?

b. Strategi pembelajaran yang bagaimanakah yang dapat mengembangkan 
belahan kanan otak secara efektif dan efisien untuk meningkatkan kemampuan berbahasa pada anak?

\subsection{Tujuan}

Tujuan dari pembahasan makalah ini yaitu untuk menjawab dan memberikan penjelasan mengenai:

a. Kurikulum yang seharusnya digunakan untuk memberdayakan kedua belahan otak untuk memperoleh kemampuan berbahasa yang utuh.

b. Strategi pembelajaran yang dapat mengembangkan belahan kanan otak secara efektif dan efisien untuk meningkatkan kemampuan bahasa pada anak.

\subsection{Manfaat}

Pembahasan makalah ini diharapkan dapat memberikan manfaat baik yang bersifat praktis maupun teoretis. Secara praktis, makalah ini hendaknya bisa menjadi masukan bagi para orang tua dan guru terutama dalam hal menyusun kurikulum pembelajaran bahasa pada anak maupun siswa didiknya. Selain itu juga bisa meningkatkan kesadaran masyarakat untuk membantu anak dalam perkembangan bahasanya dengan memberikan input yang baik dan fasilitas belajar yang memadai sehingga akan dapat mengoptimalkan kemampuan bahasa anak dan memperlancar anak dalam komunikasinya. Sedangkan secara teoretis, makalah ini diharapkan bisa merangsang pembahasan lebih lanjut mengenai usaha-usaha meningkatkan mutu dan 
kualitas pendidikan, terutama yang ada kaitannya dengan bahasa, sebagai cerminan budaya bangsa.

\section{BAB II}

\section{TINJAUAN PUSTAKA}

\subsection{Bahasa}

\subsubsection{Hakikat}

Bahasa bisa didefinisikan menurut fungsi dan bentuknya. Menurut fungsi, bahasa adalah suatu struktur yang unik yang terdiri dari bunyi-bunyi ucapan yang dipilih dan disusun secara sewenang-wenang untuk dipakai oleh suatu masyarakat sebagai alat komunikasi. Menurut bentuknya bahasa merupakan sejumlah kalimat yang tidak terbatas, namun panjang setiap kalimat terbatas, dan setiap kalimat terdiri dari sejumlah unsur yang terbatas jumlahnya. Definisi bahasa ini disampaikan oleh Simanjuntak (1991: 20) dalam penyajian makalahnya pada Pertemuan Linguistik Lembaga Bahasa Atma Jaya Keempat.

Sedangkan menurut pandangan linguistik umum sendiri, bahasa diartikan sebagai suatu sistem arbitrer yang berupa simbol-simbol vokal tertentu sebagai sarana komunikasi yang ditransmisikan secara kultural dengan karakteristik-karakteristik khusus yang membedakannya dari bahasa binatang. Pengertian bahasa seperti ini menunjukkan bahwa bahasa sebagai suatu sistem pastilah memiliki aturan main yang ajeg dan dianut oleh siapapun yang memakai bahasa tersebut, yaitu masyarakat bahasa 
(speech community) yang terikat oleh tata budaya yang mereka bentuk sendiri secara konvensional. Dengan demikian maka tampak bahwa bahasa memang merupakan cermin budaya dari penutur bahasa tersebut.

\subsubsection{Karakteristik}

Bahasa manusia berbeda dari bahasa binatang dengan adanya karakteristikkarakteristik yang khas pada sistem bahasa manusia, antara lain:

1. Bahasa manusia menggunakan simbol atau lambang-lambang arbitrer yang berupa simbol vokal, tulisan, isyarat dan kode yang telah disepakati bersama.

2. Bahasa manusia memiliki kriteria sebagai suatu sistem, yaitu mempunyai komponen-komponen yang bekerja sama dan saling mendukung untuk membangun satu kesatuan makna yang utuh. Komponen-komponen pembentuk sistem bahasa tersebut adalah komponen fonologi, morfologi, sintaksis dan semantik.

3. Bahasa bersifat universal (language universal). Ada dua pemikiran atau konsep dari ide kesemestaan bahasa ini. Pertama, bahwa pada dasarnya semua bahasa di permukaan bumi ini berasal dari rumpun bahasa yang memiliki struktur dasar yang sama, yakni bahasa Indo-Eropa/ Proto-Indo-Eropa (paham Linguistik Sejarah). Kedua, baik proses, tahap perkembangan, maupun elemen-elemen bahasa yang sedikit demi sedikit dikuasai anak tampaknya mengikuti pola yang sama di seluruh dunia (Dardjowidjojo, 1991: 63). Dengan kata lain, pemerolehan bahasa bersifat universal.

4. Bahasa merupakan perangkat sosial yang diperoleh dari proses belajar (acquisition) dan ditransmisikan secara kultural serta sepenuhnya dikondisikan oleh lingkungan. Artinya, bahasa bukan merupakan bagian dari perangkat biologis yang 
diturunkan secara genetis dari orang tua kepada anak.

\subsection{Kaitan Fungsi Otak dengan Perkembangan Bahasa}

Asumsi-asumsi umum yang berkembang di masyarakat mengenai kaitan fungsi otak dengan perkembangan bahasa selama ini meyakini bahwa kemampuan berbahasa seseorang sepenuhnya dikendalikan otak bagian kiri (hemisfer kiri). Keyakinan ini berangkat dari kesimpulan atau hipotesis yang kita tarik atas kasus dan fenomena yang terjadi di sekitar kita, yaitu bahwa cedera di daerah otak kiri dapat menyebabkan ganguan pada fungsi wicara, sementara kerusakan di daerah otak kanan tidak menimbulkan efek yang sama. Hal ini ternyata sejalan dengan teori Neurolinguistik Klasik yang menyatakan bahwa hemisfer kanan memang tidak ada kaitannya dengan fungsi kebahasaan. Lebih lanjut, Krashen (1977 dalam Cahyono 1995:259) menyebutkan lima alasan yang mendasari teori ini. Pertama, hilangnya kemampuan berbahasa lebih sering disebabkan oleh kerusakan belahan kiri otak daripada belahan kanan otak. Kedua, ketika belahan kiri otak dianastesia, kemampuan berbahasa menjadi hilang. Namun ketika belahan kanan otak dianastesia, akibat itu tidak terjadi. Ketiga, ketika bersaing dalam menerima input bahasa secara bersamaan melalui tes menyimak dikotis, telinga kanan lebih ungggul dalam ketepatan dan kecepatan pemahaman daripada telinga kiri. Keempat, ketika materi bahasa disajikan melalui penglihatan kanan dan kiri, penglihatan kanan lebih tepat dan cepat dalam menangkap materi itu. Keunggulan telinga kanan dan mata kanan ini disebabkan hubungan yang 
lebih baik antara telinga kanan dan mata kanan dengan belahan kiri otak. Kelima, pada saat melakukan kegiatan berbahasa, belahan kiri otak menunjukkan kegiatan elektris yang lebih hebat.

Dari hasil penelitian melalui tes menyimak dikotis diperoleh kesimpulan bahwa belahan kanan otak bertugas mengolah bunyi-bunyi non-verbal atau isyarat nonlinguistik dan belahan kiri otak mengolah bunyi-bunyi bahasa (Kimura sebagaimana dikutip oleh Krashen dalam Cahyono 1995:267). Hal ini menunjukkan bahwa belahan kiri otak lebih berperan dalam menangani rangsangan-rangsangan bahasa, dengan kata lain mencerminkan keunggulan belahan kiri otak dalam hal bahasa.

Namun dengan banyaknya penelitian dan pengkajian mendalam serta adanya penemuan-penemuan baru dalam bidang neurolinguistik, terbukti bahwa asumsi tersebut tidak seluruhnya benar. Krashen (1977 dalam Cahyono 1995:261) menyatakan bahwa meskipun terdapat keunggulan belahan kiri otak, tidak semua aspek bahasa dibatasi pada belahan kiri otak itu. Hal ini ditunjukkan dengan adanya dua variasi cara kerja belahan otak pada setiap orang. Pertama, sebagian orang kurang mendapat lateralisasi daripada sebagian orang yang lain. Artinya, untuk orang-orang tertentu kemampuan berbahasa dikendalikan belahan kiri dan kanan otak. Kedua, sebagian orang lebih condong pada penggunaan salah satu belahan otak kiri atau kanan secara lebih siap untuk fungsi kognitif. Dalam hal ini, dapat dikatakan bahwa tidak harus terdapat lokasi otak yang eksklusif untuk kemampuan bahasa. Sekaligus hal ini memperjelas kenyataan bahwa banyak orang yang menderita kerusakan otak yang tidak parah (dengan hilangnya kemampuan berbahasa untuk sementara) mampu 
mendapatkan kembali kemampuan penggunaan bahasa mereka (dalam tataran yang bervariasi) dengan mengalihkan fungsi pada belahan otak yang lain. Simanjuntak (1991: 9) menyuplik teori Neurolinguistik Modern yang menyatakan bahwa kedua hemisfer otak bekerja sama pada waktu berkomunikasi untuk menjamin pemahaman dan penyampaian makna yang sempurna. Hemisfer kanan mengendalikan semua fonem suprasegmental dan tona suara, ekspresi muka, gerak-gerik badan waktu bertutur dan juga makna tersirat/perumpamaan serta ungkapan-ungkapan idiomatik. Sedangkan, hemisfer kiri berfungsi mengendalikan kata-kata yang membawa maknamakna literal (tersurat) dalam kalimat. Secara umum, hemisfer kanan berfungsi untuk semua hal yang berkaitan dengan ideasi bukan bahasa dan hemisfer kiri untuk bahasa. Berikut pembagian fungsi otak berdasarkan spesialisasi kedua hemisfer tersebut:

\section{Hemisfer kiri}

Ideasi bahasa:

Membaca

Menulis

Berhitung (mengira)

Sains/teknologi

Berpikir analitis dan rasional

Sadar

Logis

Sistematis

Realistis

Positif

\section{Hemisfer kanan}

Ideasi bukan bahasa:

Musik dan lagu

Idiom-idiom bahasa automatis/

perumpamaan

Kebolehan konstruksi

Berpikir sintesis (holistis)

Tidak sadar

Intuitif

Kreatif dan inovatif

Proses kegiatan gestalt

Pengenalan muka, gambar, peta, dll.

(Simanjuntak, 1991: 17)

Jelaslah disini bahwa hemisfer kanan berperan penting dan secara aktif terlibat 
dalam proses-proses kebahasaan pada waktu berkomunikasi.

Proses spesialisasi kedua hemisfer yang biasanya terjadi sebelum usia pra sekolah ini dan sering disebut sebagai proses lateralisasi/maturasi, ternyata sangat mempengaruhi perkembangan bicara dan dominasi tangan kanan. Proses ini terjadi dari belahan otak kanan ke belahan otak kiri ( Lazuardi, 1991: 92). Proses komunikasi dimulai sejak lahir, diawali dengan si anak melakukan komunikasi non verbal (hemisfer kanan). Lalu sekitar umur 1-2 tahun, ia mulai belajar melakukan komunikasi verbal (hemisfer kiri). Proses maturasi dianggap selesai menjelang umur 6-8 tahun, pada saat anak sudah mulai dapat berbahasa lisan dan belajar menulis, membaca serta berhitung.

Lazuardi (1991: 94-95) menjelaskan bahwa selama proses lateralisasi ini sebenarnya terjadi juga proses preferensi tangan kanan, yang berkaitan dengan kegiatan motorik kompleks (menulis, menggambar, dsb). Sebagaimana telah diketahui bahwa daerah sensorimotorik tangan dan mulut sangat berdekatan. Ternyata, hal ini menyebabkan aktivasi kedua daerah itu sering terjadi secara bersamaan. Proses preferensi tangan kanan ini biasanya dimulai sekitar umur 2 tahun dan selesai pada kira-kira umur 4 tahun.

\subsection{Tahap-tahap Perkembangan Bahasa Anak}

Seperti juga halnya dalam bidang perkembangan fisiknya, maka perkembangan kognitif dan bahasa anak pun mengalami tahapan-tahapan. Tahapan ini biasanya sejalan dengan jadwal biologis yang sifatnya kodrati. Pada saat gerak motoris 
mencapai taraf tertentu, pada saat itu pula muncul kemampuan berbahasa tertentu. Menurut Dardjowidjojo (1991: 67) kemampuan ini bermula pada saat indeks kematangan fisik telah mencapai $65 \%$ dari nilai kedewasaan.

Jadwal perkembangan ini berjalan secara berurutan sehingga seorang anak tidak dapat "dipaksa" untuk berbuat lain kecuali mengikuti jadwal ini dengan patuh. Namun, tidak jarang orang tua--dengan niat baik membantu mendidik anak-memaksakan diri kepada anak dengan cara "orang tua" tanpa mempedulikan cara "anak" dan tingkat perkembangannya.

Contoh dialog berikut mengungkapkan bahwa apabila belum sampai pada waktunya yang tepat, tidak mungkin kesalahan bahasa anak itu dibetulkan.

Child : Nobody don't like me.

Mother : No, say "nobody likes me".

Child : Nobody don't like me.

Mother : No, say "nobody likes me".

Child : Nobody don't like me.

[Sesudah mengulangi dialog ini tujuh kali lagi, sang ibu akhirnya berkata:]

Mother : No! Now listen carefully! Say, "Nobody...likes...me!"

Child : Oh! Nobody don't likes me!

(Mc Neil 1966, dikutip dari Berstein dan Tiegerman 1985: 76, dalam Purwo 1991: 185)

Dalam contoh ini, anak belum mencapai tahap perkembangan penggunaan pola negatif sebagaimana yang diharapkan. Sekaligus terungkap bahwa bagaimanapun 
gigihnya usaha orang tua memaksakan "niat mendidiknya", hanya akan mendapatkan kesia-siaan kalau memang belum tiba saatnya. Dan selama itu pula anak akan memakai caranya sendiri untuk sampai pada tahap"sama dengan bahasa orang dewasa". Justru hal ini mencerminkan bahwa anak berada dalam proses belajar dan tahap perkembangan gramatika.

Berikut tahap-tahap perkembangan bahasa menurut beberapa ahli:

1. Menurut Myklebust (1964) dalam Lazurdi (1991: 98-99):

a. Lahir sampai 9 bulan

Anak mulai mendengar dan mengerti, kemudian berkembanglah inner language atau pengertian konseptual yang sebagian besar adalah non verbal.

b. Sampai 12 bulan

Anak berbahasa reseptif auditorik; belajar mengerti apa yang dikatakan dan pada umur 9 bulan belajar meniru kata-kata spesifik, misalnya muh, dada, kemudian menjadi mama, papa, dsb.

c. Sampai 7 tahun

Anak berbahasa ekspresif auditorik, termasuk persepsi auditorik kata-kata dan menirukan suara. Pada masa ini terjadi perkembangan bicara dan penguasaan pasif, kosa kata sekitar 3000 buah.

d. Umur 6 tahun dan seterusnya

Anak berbahasa reseptif visual (membaca). Pada waktu masuk sekolah, ia belajar membandingkan bentuk tulisan dan bunyi perkataan. Untuk melaksanakan hal ini dibutuhkan integrasi cross-modal. 
e. Umur 6 tahun dan seterusnya

Anak berbahasa ekspresif visual (mengeja dan menulis). Membaca adalah suatu proses reseptif, dimana anak belajar mengenal huruf dan berusaha menghubungkan dengan pengertian auditoriknya. Menulis adalah proses mengubah bentuk verbal menjadi bentuk oral, menganalisis secara fonetik dan kemudian menerjemahkannya menjadi suatu pola linguistik manual motorik yang dapat dimengerti.

2. Menurut Lundsteen (1981) dalam Lazuardi (1991: 99), perkembangan bahasa dapat dibagi dalam tiga tahap:

a. Tahap Pralinguistik

0-3 bulan (gurgle - coo), bunyinya di dalam dan berasal dari tenggorokan.

3-12 bulan (meleter), bunyinya ke depan dan banyak memakai bibir dan langit- langit, misalnya ma, da, di.

b. Tahap Protolinguistik

12 bulan sampai 2 tahun (walk-talk), anak sudah dapat mengerti dan menunjukkan alat-alat tubuh. Ia mulai dapat berbicara beberapa patah kata (kosakatanya dapat mencapai 200 - 300 buah).

c. Tahap Linguistik

2-6 tahun atau lebih, anak mulai belajar tata bahasa dan perkembangan kosa katanya dapat mencapai 3000 buah.

3. Menurut Lenneberg (1969) dalam Dardjowidjojo (1991: 68), terdapat korelasi antara gerak motoris dan perkembangan bahasa sebagai berikut: 
Umur Gerak Motoris

0,5 Duduk ditopang tangan;

"kranggehan"

$1,0 \quad$ Berdiri; jalan dipapah satu tangan

1,5 Genggam-lepas jadi kuat; cara jalan seperti robot; turun terap mundur

\section{Kemampuan Kebahasaan}

Bunyi menjadi ocehan konsonantal

Reduplikasi silabik; tanda-tanda mengerti kata; pemakaian bunyi untuk orang dan barang

Pengertian 3-50 kata secara non frasa; deretan bunyi dan pola intonasi

2,0 Lari-jatuh; naik terap satu kaki di muka Mengerti 50 kata lebih; frasa dua kata; banyak omong; tidak mengoceh lagi

2,5 Loncat dengan dua kaki; berdiri dengan Tambahan kata tiap hari; ujaran satu kaki; membuat tumpukan 6 dadu tiga kata; mengerti hampir semua; masih banyak salah gramatikal

3,0 Jingkat 3 meter; naik terap gantian kaki; Kosa kata sekitar 100; tanda bahasa dekat dewasa; kesalahan sintaksis berkurang; sistematik; dapat diduga

4,5 Loncatan tali; loncat satu kaki; dapat jalan di garis

Bahasa terbentuk; anomali gramatik terbatas pada yang tak lumrah

Dari tabel ini, yang menjadi tolok ukur bukanlah umur melainkan kemampuan gerak fisiknya. Umur hanyalah merupakan "ancar-ancar" kapan gerak 
motoris itu umumnya muncul.

Selama berada pada tahap-tahap perkembangan ini, anak mendengarkan contoh dari orang dewasa, mencerna, membuat hipotesis, merevisi hipotesis untuk kemudian menghasilkan bentuk bahasa yang dapat diterima (acceptable). Dalam bidang fonologi, ia dituntun oleh perkembangan biologis dan neurologisnya. Sedangkan di bidang semantik, ia berjalan selaras dengan perkembangan kognisinya. Seluruh anak di dunia pada prinsipnya mengikuti jadwal alam tahap-tahap perkembangan yang sifatnya universal.

\subsection{Faktor-faktor yang Mempengaruhi Pemerolehan Bahasa}

Pada dasarnya faktor-faktor yang berpengaruh terhadap pemerolehan bahasa ada dua, yaitu faktor internal dan eksternal. Faktor internal sendiri meliputi segala sesuatu yang berkaitan dengan pandangan, motivasi dan sikap alami atau potensi pebelajar terhadap bahasa yang dipelajarinya. Hal tersebut dapat diperinci lagi, antara lain berupa minat, bakat, intelejensi, kemampuan kognitif, kepribadian, umur, dan sifat-sifat alami pebelajar seperti tingkat keingintahuan yang tinggi, sikap suka meniru, dan lain-lain. Sementara faktor eksternal meliputi keadaan fisik pebelajar menyangkut kondisi otak, fungsi pendengaran, sistem organ bicaranya dan faktor keluarga serta lingkungan sosial tempat pebelajar itu berada. Cahyono (1995:282) menyebutkan empat persyaratan dasar pemerolehan bahasa, yakni tidak adanya gangguan indera pendengaran, intelegensi normal, tidak ada gangguan pada saraf artikulasi, dan kesempatan untuk berinteraksi dengan pihak lain denga menggunakan bahasa itu. 
Seorang bayi dilahirkan dengan kapasitas biologi yang sudah diprogramkan untuk dapat memproses suara bicara dan menguasai bahasa manapun yang disuguhkan padanya dengan keakuratan seperti penutur asli. Kapasitas biologi bawaan ini dikenal dengan istilah "Language Acquisition Device" (LAD).

Chomsky (1968) dalam Lazuardi (1991: 101) berpendapat bahwa sebagian besar kemampuan bicara manusia sebenarnya ditentukan oleh faktor genetikanya (LAD) dan bahwa setiap anak sudah dilengkapi dengan suatu alat perkembangan bahasa. Kemampuan alami itu bekerja secara otomatis ketika anak terpajan pada bahasa. Meskipun demikian, faktor-faktor genetis ini barulah sekedar suatu potensi yang perlu diasah dengan memberikan stimulus-stimulus terhadap fungsi sensorimotoriknya pada masa-masa sensitif perkembangan bahasa anak. Input konstan dalam jumlah cukup yang dapat digunakan untuk mengolah keteraturan (regularities) bahasa (Cahyono 1995:286). Jelas di sini, anak melakukan pemerolehan bahasa secara aktif dengan mengolah keajegan-keajegan dalam apa yang didengarnya dan kemudian menerapkannya dalam apa yang dikatakannya.

Selain itu, perkembangan LAD ini juga dipengaruhi oleh proses internal pada fungsi otak, yaitu proses lateralisasi/maturasi. Proses ini sangat penting dalam pembelajaran anak, terutama dalam penentuan kesiapan mengikuti pendidikan membaca, menulis dan berhitung. Gangguan pada proses maturasi kadang-kadang akan bermanifestasi dalam bentuk disfungsi minimal otak dengan gejala disfasia dan gangguan berbicara lainnya. Di lain pihak, dari penelitian genetika dan hormonal, ditemukan fenomena bahwa prose maturasi pada wanita cenderung lebih cepat dari 
pada pria, sehingga perkembangan verbalnya lebih cepat pula. Proses maturasi pada laki-laki mengalami keterlambatan kurang lebih dua tahun. Sementara anak laki-laki yang memperlihatkan gejala keterlambatan bicara biasanya memiliki kemampuan otak kanan yang menonjol, misalnya di bidang olah raga, kesenian dan matematika. Namun demikian, fenomena ini tidak bisa begitu saja digunakan untuk menjelaskan kasus umum yang lain, yaitu bahwa sekolah-sekolah jurusan bahasa lebih banyak memiliki siswa perempuan dibandingkan jurusan lain.

Proses pemerolehan bahasa secara garis besar juga dipengaruhi oleh lingkungan. Menurut Gottlieb (1983) dalam Lazuardi (1991: 100) perkembangan otak ditentukan selain oleh faktor genetik juga oleh faktor lingkungan dan pengalaman si anak. Tetapi keberadaan faktor lingkungan ini hanyalah sebagai input pemerolehan bahasa itu sendiri dan tidak secara langsung mempengaruhi tahapan dan kecepatan prosesnya. Lebih lanjut Chomsky (1968) dan Lightfoot (1982) dalam Lazuardi (1991: 101) menyatakan bahwa pengaruh lingkungan sekedar merupakan pencetus (trigger) yang berperan mengaktivasi dan menopang bahasa tersebut. Lingkungan yang bersifat menopang terwujud dalam pola pengasuhan yang merupakan kerangka (framework) di mana orang tua melakukan interaksi dan komunikasi dengan anak untuk memenuhi kebutuhan fisik dan mental si anak. Seorang anak yang tumbuh dalam dua atau tiga tahun pertama membutuhkan interaksi dengan pemakai bahasa yang lain agar "kemampuan bahasa"-nya dapat digunakan untuk keperluan praktis. Oleh karena itu, keberhasilan perkembangan bahasa inipun ditentukan oleh pola pengasuhan yang aktif yang berupa program-program intensif yang telah disesuaikan dengan perkembangan 
kognitif anak.

Secara lebih sempit, proses pemerolehan bahasa memiliki kaitan dengan latar belakang keluarga (Dardjowidjojo, 1991: 84). Penguasaan bahasa memerlukan input yang lebih banyak dan lebih baik jika berasal dari keluarga yang berlatar belakang baik pula. Sebuah penelitian di Inggris oleh Bernstein menghasilkan apa yang kini dikenal sebagai teori "Language Deficit" yang menjelaskan bahwa penguasaan bahasa dipengaruhi oleh keadaan alam sekitar, termasuk keluarga--keluarga yang mampu menelurkan penutur yang baik, sedangkan yang kurang mampu menghasilkan penutur yang kurang baik pula.

\subsection{Tinjauan Kurikulum Pendidikan Pra Sekolah di Indonesia}

Kurikulum pendidikan pra sekolah yang dijabarkan dalam Garis-garis Besar Program Kegiatan Belajar Taman Kanak-kanak (GBPKB-TK) pada dasarnya merupakan seperangkat kegiatan belajar yang direncanakan untuk dilaksanakan dalam rangka menyiapkan dan meletakkan dasar-dasar bagi pengembangan pembentukan perilaku dan kemampuan dasar yang disesuaikan dengan tahap perkembangan anak.

\subsubsection{Fungsi}

Program kegiatan belajar TK berfungsi untuk:

1. Mengembangkan seluruh kemampuan yang dimiliki anak sesuai dengan tahap perkembangannya;

2. Mengenalkan anak pada dunia sekitar; 
3. Mengembangkan sosialisasi anak;

4. Mengenalkan peraturan dan menanamkan disiplin pada anak;

5. Memberikan kesempatan kepada anak untuk menikmati masa bermainnya.

\subsubsection{Program Kegiatan Belajar}

Program kegiatan belajar di TK dibagi dalam dua kegiatan utama, yaitu:

1. Pembentukan perilaku.

Program pembentukan perilaku merupakan kegiatan yang dilakukan secara terus menerus dan ada dalam kehidupan sehari-hari anak di TK sehingga menjadi kebiasaan yang baik. Program tersebut meliputi Moral Pancasila, Agama, Perasaan/Emosi, dan Kemampuan Bermasyarakat serta Disiplin. Progam ini ditujukan untuk mempersiapkan anak sedini mungkin untuk mengembangkan sikap dan perilaku yang sesuai dengan norma masyarakat.

2. Pengembangan Kemampuan Dasar.

\section{A. Daya Cipta.}

Bertujuan untuk membuat anak kreatif, yaitu lancar, fleksibel dan orisinil dalam bertutur kata, berpikir, serta berolah tangan dan tubuh sebagai latihan motorik halus dan kasar.

B. Bahasa.

Bertujuan agar anak didik mampu berkomunikasi secara lisan dengan lingkungan. Kemampuan bahasa yang diharapkan tercapai antara lain:

- Menirukan kembali urutan angka, kata ( latihan pendengaran ). 
- Mengikuti beberapa perintah sekaligus.

- Menggunakan dan dapat menjawab pertanyaan apa, mengapa, dimana, berapa, bagaimana, dan sebagainya.

C. Daya Pikir.

Bertujuan agar anak didik mampu menghubungkan pengetahuan yang sudah diketahui dengan pengetahuan baru yang diperolehnya. Kemampuan yang diharapka tercapai antara lain:

- Menyebutkan urutan bilangan.

- Membilang (mengenal konsep bilangan) dengan benda-benda.

- Menghubungkan konsep bilangan dengan lambang bilangan (anak tidak disuruh menulis)

D. Keterampilan.

Bertujuan untuk mengembangkan keterampilam motorik halus anak didik dalam berolah tangan. Kemampuan keterampilan tersebut antara lain:

- Membentuk dengan tanah liat/plastisin/adonan tepung atau pasir.

- Melipat kertas.

E. Jasmani.

Bertujuan untuk mengembangkan motorik kasar anak didik dalam berolah tubuh untuk pertumbuhan dan kesehatannya. Kemampuan yang diharapkan antara lain:

- Berlari lurus, berjingkat, angkat tumit, dsb. 
- Meloncat dari ketinggian 20-50 cm sambil menghadap ke arah tertentu.

\section{BAB III}

\section{PEMBAHASAN}

\subsection{Pengembangan Kurikulum yang Berimbang}

Dalam rangka mengembangkan kurikulum pendidikan pra sekolah yang baik, rasanya kita perlu menengok kurikulum pendidikan di negara maju yang lebih menekankan dahulu pemantapan fungsi otak kanan sebelum dimulai dengan pendidikan otak kiri. Anak-anak pra sekolah dan kelas awal sekolah dasar dididik melakukan komunikasi pragmatik, mengadakan kontak mata, menanamkan pola gilirbicara, melakukan sosialisasi dan mengendalikan emosi. Komunikasi dan pengertian berbahasa yang sederhana mempunyai arti yang sangat penting dan menjadi landasan untuk pendidikan selanjutnya, yaitu pendidikan otak kiri. Latihan berkomunikasi itu dilaksanakan di antara anak-anak, dan guru hanya berperan sebagai pendorong terhadap kegiatan tersebut. Hal ini ternyata juga sangat membantu anak laki-laki yang pada umumnya mengalami keterlambatan dalam proses maturasi (Lazuardi, 1991: 9195). Oleh karena itu, ada baiknya kurikulum pendidikan kita ditinjau kembali dengan cara memberi keseimbangan kepada kedua belah hemisfer dengan memberi penekanan yang sama pada mata pelajaran-mata pelajaran yang berkaitan dengan pemikiran 
intuitif (hemisfer kanan) dan pemikiran verbal (hemisfer kiri).

Pengajaran bahasa, terutama bahasa asing, sebaiknya juga menggunakan prinsip keseimbangan dan lateralisasi ini, yaitu memanfaatkan kedua hemisfer otak dengan memantapkan dulu fungsi otak kanan sebelum memulai dengan menstimulus otak kiri. Komunikasi pragma 22 „In semantik yang sederhana didahulukan pengajarannya, dan baru pada tahap selanjutnya dipelajari komunikasi yang lebih kompleks, yaitu dengan sintaksis dan semantik yang lebih mendalam. Dengan demikian, proses pembelajaran akan lebih berkesan di otak yang akan diikuti dengan penguasaan kemampuan berbahasa yang utuh.

Sering diasumsikan bahwa anak mulai "berbahasa" pada waktu ia mampu mengeluarkan kata-kata pertamanya, yakni sekitar usia satu tahun. Akan tetapi, sesungguhnya sudah sejak masa-masa awal setelah kelahirannya anak mampu berkomunikasi dengan ibu dan orang dewasa di sekitarnya. Namun demikian, konsep berkomunikasi di sini hendaknya tidak dipahami sebagai kemampuan berbahasa ekspresif yang kompleks, melainkan terbatas pada bentuk-bentuk non verbal yang bersifat terbatas dan lebih untuk fungsi psikologis. Selanjutnya bersamaan dengan perkembangan motoriknya, anak akan mengalami tahap-tahap perkembangan bahasanya. Dalam hal ini anak-anak tidak belajar secara pasif melainkan secara aktif berusaha menyerap input-input yang berasal dari lingkungannya, memprosesnya untuk kemudian menghasilkan ujaran-ujaran yang "acceptable". Tarigan (1988: 46) mengkonfirmasikan fenomena ini dengan menyatakan bahwa proses belajar bahasa sama sekali tidak automatis bagi anak kecil. Anak sering sekali mendapatkan 
permulaan yang salah dan kerapkali benar-benar frustrasi. Mereka selalu jatuh bangun dalam proses menghasilkan bahasa yang dapat diterima oleh lingkungan sosialnya. Dongeng mengenai kemudahan dan kecepatan pemerolehan bahasa oleh anak-anak akan mengingatkan kita kepada dongeng yang menyenangkan pada masa kanak-kanak (Tarigan, 1988: 46). Jika demikian halnya, kita tidak seharusnya membiarkan anak berjuang sendiri dalam pemerolehan bahasanya. Sebisa mungkin kita tidal terlalu banyak menunggu apabila si anak agak tertinggal dalam perkembangannya, dengan harapan ia akan mampu menyusul (catch up) pada perkembangan selanjutnya. Di sinilah pentingnya kita mengadakan deteksi dini dan analisis serta evaluasi terhadap semua aspek perkembangan agar antisipasi bisa dilakukan pada saat yang tepat apabila terjadi gangguan pada wicara maupun bahasanya.

Sementara itu, kita juga tidak seharusnya terlalu banyak menuntut dan memaksakan dalam menghadapi proses perkembangan bahasa anak dengan memberikan rangsangan-rangsangan yang bersifat memacu perkembangan anak melampaui jadwal alaminya. Orang tua sering berambisi agar anaknya cepat pandai dengan memberikan bermacam-macam program percepatan, seperti les-les tambahan setelah pulang sekolah seakan-akan si anak "diperam" supaya cepat matang. Hal semacam ini pernah terjadi pada waktu yang lampau di Jepang dan Korea Selatan di mana kurikulum yang berat menimbulkan banyak kegagalan, seperti sering timbulnya stres dan frustrasi pada anak. Soal "pengkarbitan" ini pernah dimuat di suatu artikel yang berjudul "The Kids in the Pressure-Cooker" dalam The Sydney Morning Herald (Lazuardi, 1991: 129). Artikel ini meragukan buku "Teaching Your Baby to 
Read/Math”, karena pada umur sekecil itu pengertiannya belum ada. Tampaknya hal inilah yang sedang diterapkan dalam program pendidikan bagi anak Taman-taman Kanak di negara kita. Mereka talah diajarkan membaca dan menulis lebih dini yang justru akan menghambat perkembangan anak yang belum mencapai tahap berbahasa tulis. Pemaksaan pendidikan dalam tahun-tahun permulaan sekolah ini ternyata bisa menimbulkan suatu trauma psikogenik yang mempunyai dampak buruk pada pendidikan di kemudian hari (Lazuardi, 1991: 129).

Dalam hal penyusunan kurikulum pendidikan dasar (Primary School), sebaiknya kita menengok program-program pendidikan di negara maju yang telah terbukti berhasil dalam mengangkat kualitas generasi muda mereka. Sebagai ilustrasi pertama adalah pendidikan di Jepang yang kini telah mengalami perubahan yang mendasar. Sejak kecil anak sudah diajar bergaul dan bekerja sama dalam memecahkan suatu permasalahan. Sementara di negara-negara barat (Amerika, Eropa, Australia), anak-anak di sekolah dasar hampir tidak pernah diberikan pekerjaan rumah. Mereka berpendapat bahwa di rumah anak-anak harus bermain dan bergaul. Hal ini memberikan si anak kesempatan untuk mempunyai landasan yang teguh dalam membina perkembangannya sehingga kualitasnya baik. Dengan pematangan emosi dan sosialisasi ini maka timbulnya ansietas dan fobia sekolah tidak akan terjadi.

Selanjutnya Purwo (1991: 190) menyebutkan bahwa masa ideal belajar bahasa adalah pada masa anak duduk di bangku sekolah dasar dan sekolah lanjutan tingkat pertama. Kemampuan untuk memperoleh bahasa pertama berakhir setelah proses lateralisasi selesai yang terjadi pada masa pubertas diperbarui (Lenneberg 1967 dalam 
Cahyono 1995:272). Usia antara 6 sampai 15 tahun tersebut adalah masa emas untuk belajar bahasa, terutama bahasa kedua atau bahasa asing. Namun demikian, Tarigan (1988: 46) berargumentasi bahwa bukan pubertas (antara 6-15 tahun) yang merupakan titik pintas bagi lateralisasi fungsi bahasa. Tetapi bahwa lateralisasi pada hakikatnya sudah sempurna pada usia 4 atau 5 tahun bahkan lebih cepat, artinya masa krisis bahasa harus diperbaiki dan diturunkan menjadi antara usia 2 dan 4 atau 5 tahun. Temuan-temuan dalam kasus Genie, misalnya, telah memperkuat pandangan yang menyatakan bahwa pemerolehan bahasa pertama dalam tataran tertentu dapat dilakukan setelah periode kritis. Apabila rangsangan bahasa tidak terjadi selama periode waktu ini, pemerolehan bahasa secara normal tergantung pada daerah lain dari otak dan berlangsung secara kurang efisien. Krashen dan Hashman ( sebagaimana dikutip olek Fromkin, et al. 1981 dalam Cahyono 1995:271) menyatakan bahwa lateralisasi berakhir pada usia lima tahun dan proses itu tidak berhubungan dengan periode kritis yang membatasi pemerolehan bahasa. Sementara ini, kedua hipotesis tersebut masih diperdebatkan ketepatannya.

Terlepas dari argumentasi mengenai masa sensitif bahasa pada anak, hendaknya memang waktu-waktu ini tidak disia-siakan. Mengingat pada umur ini otak manusia masih elastis sehingga mampu menyerap, mencerna, dan meniru dengan sempurna. Otak dan organ bicara pada anak usia ini masih memungkinkan menghasilkan imitasi bahasa dengan ketepatan dan keakuratan yang tinggi. Berbeda dengan orang dewasa yang telah melewati masa kritis bahasa. Ia tidak akan dapat menguasai bahasa asing seperti halnya anak kecil. Karena itulah, maka betapapun 
hebatnya seseorang berbahasa asing, apabila ia menguasainya setelah dewasa tetap akan diketahui bahwa ia bukanlah penutur asli. Dalam hal feature fonetik dan suprasegmental, secara neurologis ia sudah tidak bisa lagi menguasai dengan sempurna seperti halnya anak kecil--tentunya dengan pengecualian di sana-sini.

Dalam hal ini setiap argumentasi yang mengemukakan bahwa "kian muda kian baik" atau "the younger is the better" dalam pemerolehan bahasa masih harus diterima dengan kecurigaan. Dari banyak situasi faktor-faktor neurologis dan non-linguistik, kriteria kompetensi komunikatif, jumlah pembukaan serta faktor sosial psikologis tertentu, anak-anak memang mendapatkan keuntungan yang menjadikannya superior dalam pemerolehan bahasa (Tarigan, 1988: 47). Anak-anak cenderung tidak segansegan membuat kesalahan ditunjang dengan sifat keingintahuannya yang tinggi, mungkin akan menjadikannya lebih bersemangat belajar bahasa kedua dibandingkan anak yang lebih tua, apalagi bila didukung dengan kondisi keluarga atau lingkungannya yang dwibahasa. Dengan kata lain kesuperioran anak-anak dalm pemerolehan bahasa di bawah kondisi seperti ini tidak perlu dikaitkan dengan keterampilan belajar yang lebih unggul. Dengan memberikan jumlah dan kualitas pembukaan yang sama maka seorang dewasa agaknya bisa melakukan sama baik (Tarigan, 1988: 48). Didukung dengan kemampuan berpikir logis dan komprehensif dalam memahami dan menerapkan atuan-aturan yang ada dalam bahasa asing orang dewasa bisa jadi lebih unggul. Namun, perlu diingat bahwa orang dewasa cenderung sulit untuk mendapatkan kesempatan dan keuntungan-keuntungan yang diperoleh anak yang lebih muda tersebut, seperti kapasitas biologis, situasi dukungan sosial, waktu 
dan sebagainya. Sehingga tidak ada alasan untuk tidak memanfaatkan keuntungan dan keunggulan tersebut pada waktu yang tepat.

\subsection{Strategi Pembelajaran Bahasa}

Adalah lebih cermat dan tepat menggunakan "cara belajar anak" sebagai pedoman atau ancang-ancang bagi penentuan langkah pembelajaran bahasa pada anak. Berikut Tarigan (1988: 8-12) menerakan cara belajar bahasa pada anak--cara mambangun bahasa secara kreatif.

a. Menggunakan pemahaman non-linguistik sebagai dasar pemahaman dan pemikiran bahasa. Dengan kata lain, memantapkan dulu fungsi hemisfer kanan otak sebagai landasan bagi perkembangan fungsi bahasa otak kiri. Hal ini sama dengan prinsip lateralisasi sebagaimana telah dikemukakan sebelumnya.

b. Menggunakan segala sesuatu yang penting, menonjol dan menarik hati (pusat perhatian) dalam pembangunan sistem bahasa dan kosa kata. Pemahaman anak tentang segala sesuatau pada umumnya dimulai dari benda-benda abstrak, termasuk dalam pemahaman bahasa. Pada proses awal ini, tentu saja diperlukan suatu media berupa visualisasi/ilustrasi yang menarik untuk menimbukan kesan yang mendalam. Nelson, misalnya, menyarankan dua jenis obyek yang bisa dijadikan media yang menarik; yaitu (i)

obyek-obyek yang dapat membuat anak-anak aktif dan giat (contohnya: topi, sepatu, kunci, palu, dan lain-lain); (ii) obyek yang bergerak dan berubah (seperti: mobil, jam 
dan lain-lain).

c. Menganggap bahasa dipakai secara referensial atau ekspresif. Berkaitan dengan fungsi bahasa sebagai alat komunikasi, anak cenderung menggunakan bahasa untuk fungsi referensial (pengacuan untuk menyebutkan suatu benda, gejala/ peristiwa) dan ekspresif (mengungkapkan pendapat, perasaan (sedih, marah, dan lain-lain), bersosialisasi secara aktif) tentu saja dalam bentuk-bentuk yang masih sederhana. Orang tua biasanya menyederhanakan fungsi referensial ini dengan melibatkan anak dalam komonikasi tentang apa yang terjadi di sini dan kini, mengurangi pembicaraan tentang perasaan, dan menghindari percakapan tentang peristiwa yang terjadi di luar lingkungan anak.

d. Mengamati cara orang lain mengekspresikan makna. Dalam proses awal belajar bahasa anak berbicara sedikit dan seakan-akan lebih banyak mengamati untuk melihat bagaimana makna dan ekspresi verbal saling berhubungan. Pengamatan tersebut tentu saja lebih banyak terfokus pada ujaran-ujaran pengasuh di keluarganya, sebagai lingkungan terdekat. Para pengasuh (care taker), seperti ayah, ibu, kakek, nenek, dan lain-lain sering menyederhanakan ujaran-ujarannya selama berinterkasi dengan anak, yang terlihat pada struktur kalimat, banyaknya pengulangan, serta kecenderungan memadukan sejumlah bentuk yang berhubngan dengan celoteh bayi (baby talk), misalnya susu menjadi cucu. Penyederhanaan ini sebenarnya berfungsi secara psikologis daripada kognitif, yaitu membantu anak menangkap makna kalimat daripada membantu dalam mempelajari pengucapan (Cahyono 1995:284).

e. Mengajukan pertanyaan untuk memancing data yang diinginkan. Dalam 
tahap perkembangan bahasanya, anak akan mencapai tahap mengajukan pertanyaan (usia tiga tahun) yang disampaikan secara berulang-ulang. Pengajuan pertanyaan itu berfungsi untuk menjaga keberlangsungan percakapan dan interaksi yang mungkin menjadi tujuan anak. Misalnya, dalam percakapan, anak sering kali mengemukakan pertanyaan mengapa. Apabila pertanyaan ini dijawab, kadang-kadang anak bertanya lagi dengan pertanyaan mengapa yang lain yang kadang merepotkan untuk menjawab dengan jelas dan tepat. Agaknya setiap orang tua mempunyai pengalaman yang sama dalam mengahadapi hal ini. Mengemukakan pertanyaan mengapa dapat menjawab kebutuhan anak untuk melakukan percakapan sosial, yaitu percakapan interaktif yang memungkinkan dilakukan dalam waktu cukup lama.

f. Menirukan apa yang dikatakan orang lain. Peniruan yang dimaksud di sini bukanlah proses yang terus-menerus seperti beo, melainkan ulangan dari apa yang diucapkan orang dewasa untuk menguji ketepatan pelafalan dirinya sendiri. Namun hendaknya pengasuh tidak menyalahartikan strategi imitasi ini. Jangan pernah mengharapkan anak akan menghasilkan ujaran yang persis sama seperti yang kita harapkan. Anak tetap akan melakukan seleksi dan mengubah gagasan pasif ini menjadi gagasan aktif, untuk kemudian menghasilkan ujaran yang sesuai dengan pemahamannya. Ujaran yang tidak " membeo" dan masih sering keliru justru menunjukkan bahwa mereka sedang dalam proses belajar.

g. Menggunakan beberapa “ prinsip operasi” umum untuk menetapkan bahasa. Prinsip operasi umum yaitu generalisasi terhadap aturan-aturan dalam struktur bahasa yang dipelajarinya. Dengan mengenali aturan-aturan dasar, biasanya anak akan mampu 
mengidentifikasi keajegan-keajegan yang ada pada fenomena tertentu dan menerapkan pada fenomena yang lain.

h. Membuat sebanyak mungkin dari yang telah dimiliki. Sifat alami dan khas dari anak adalah keberanian yang luar biasa untuk mencoba. Melalui Trial and Error dalam pengalaman berbahasanya, ia berusaha memperkaya kosakata dan memperluas penguasaaan bahasanya. Oleh karena itu, sering kali kita menemui bentuk-bentuk ujaran anak yang tidak dapat dijelaskan dengan aturan bahasa yang ada.

i. Menghasilkan bahasa dan melihat cara orang lain ber-responsi. Anak-anak biasanya menguji ketepatan ujarannya dengan melibatkan diri dalam komunikasi. Jika ujarannya memperoleh respon yang diharapkan maka dianggap ungkapannya itu sudah benar. Sebaliknya, jika respon yang diberikan orang lain tidak sesuai yanng diharapkan, ia akan mencoba menghasilkan ujaran-uajran baru samapai memperoleh respon yang diinginkan. Oleh karena itu, pengasuh seharusnya mendorong adanya interaksi dengan memberi umapn balik yang merangsang komunikasi lebih lanjut, dan terutama menghindarkan kata-kata perintah serta terlalu banyak pertanyaan.

Dengan memperhatikan "cara anak" memperoleh bahasanya, kita dapat menentukan langkah-langkah yang dapat membantu, mendukung atau mempermudah proses tersebut. Usahakan jangan memaksakan "cara orang tua" dan terlalu banyak memberikan intervensi yang tidak perlu dan bersifat menghambat, seperti teguran, kecaman, dan hukuman. Sebaliknya, berikanlah "reinforcement" atau penguatan yang dapat merangsang kreativitas si anak 


\section{BAB IV \\ SIMPULAN DAN SARAN}

\subsection{Simpulan}

Dari pembahasan makalah ini dapat ditarik beberapa simpulan sebagai berikut:

a. Kurikulum pendidikan di Indonesia saat ini, terutama dalam pembelajaran bahasa, masih berat sebelah dan belum mempertimbangkan pola perkembangan neurologis anak. Oleh karena itu penguasaan kemampuan berbahasa anak tidak bersifat utuh (partial) dan hanya menonjol pada aspek-aspek tertentu saja.

b. Dalam menentukan langkah-langkah pembelajaran bahasa yang efektif pada anak perlu diperhatikan strategi-strategi pembelajaran yang menggunakan cara "anak", dan bukannya cara "orang tua".

\subsection{Saran}

Untuk meningkatkan kualitas anak-anak, pengasuhan dan pendidikan yang 
tepat--dimana bahasa dan komunikasi sebagai peran kuncinya--perlu ditingkatkan. Hal ini bisa dicapai apabila orang tua bekerja sama dengan masyarakat dan pemerintah dalam hal :

a. Membuat tahapan perkembangan bahasa (language milestone scale) pada balita.

b. Mengadakan deteksi dan intervensi dini terhadap gangguan perkembangan dan komunikasi.

c. Menyusun kurikulum pendidikan yang berpedoman pada prinsip pola lateralisasi fungsi otak, terutama memberdayakan fungsi otak kanan.

d. Memanfaatkan masa kritis bahasa anak seefisien mungkin untuk membantu pemerolehan bahasa mereka secara lebih efektif.

e. Memperhatikan "cara anak" dan tidak memaksakan "cara orang tua" dalam pembelajaran bahasa.

f. Mengadakan evaluasi perkembangan bahasa yang holistis, dengan kata lain dapat menilai penguasaan fungsi-fungsi bahasa yang dibawahi kedua belahan otak. 


\section{REFERENCES}

Cahyono, Bambang Yudi. 1995. Kristal-kristal Ilmu Bahasa. Surabaya: Airlangga University Press.

Dardjowidjojo, Soenjono (penyunting). 1991. PELLBA 4: Linguistik Neurologi. Jakarta: Kanisius.

Depdikbud. 1994. Garis-garis Besar Program Kegiatan Belajar Taman Kanak-kanak. Jakarta: Depdikbud.

Lazuardi, Samuel. 1991. Perkembangan Otak Anak Sesuai dengan Kemampuan Berbahasanya. Dalam Soenjono Dardjowidjojo (penyunting). PELLBA 4: Linguistik Neurologi. Jakarta: Kanisius.

Purwo, Bambang Kaswanti. 1991. Perkembangan Bahasa Anak: Pragmatik dan Tata Bahasa. Dalam Soenjono Dardjowidjojo (penyunting). PELLBA 4: Linguistik Neurologi. Jakarta: Kanisius.

Rudolph, Marguerita and Dorothy H. Cohen. 1984. Kindergarten and Early Schooling. United States of Amerika: Prentice-Hall, Inc.

Simanjuntak, M. 1991. Neurolinguistik dan Afasiologi: Satu Kewujudan Kerjasama yang Saling Menguntungkan. Dalam Soenjono Dardjowidjojo (penyunting). PELLBA 4: Linguistik Neurologi. Jakarta: Kanisius.

Suharto, S. (1997). Musik dan Bahasa. Jurnal Media, 20(4), 286-393

Suharto, S.(200). Peran Seni dalam Pengoptimalan Fungsi Otak, Jurnal Media, 23(3), $400-411$

Suharto, S. (2011). Permasalahan Musikal dan Lingual dalam Penerjemahan Lirik Lagu (The Musical and Linguistic Problems in Lyrics Translation). Harmonia: Journal Of Arts Research And Education, 7(2). doi:http://dx.doi.org/10.15294/harmonia.v7i2.756

Tarigan, Henry Guntur. 1988. Pengajaran Pemerolehan Bahasa. Bandung: Angkasa. 